\title{
READING STRATEGIES FOR NON-ENGLISH DEPARTMENT STUDENTS: HOW IMPORTANT IS IT?
}

\author{
Zusana E. Pudyastuti \\ Sekolah Tinggi Informatika \& Komputer Indonesia \\ e-mail: zusana76@gmail.com,zusanacr@stiki.ac.id
}

\begin{abstract}
Lack of English knowledge, lack of vocabulary and incapability in using reading strategies might become the reasons of most higher education students, particularly the students of non-English department, to feel reluctance reading in L2. For becoming successful and strategic readers, reading strategies are crucial. Unfortunately, the nonEnglish department students are not taught about reading strategies which hinders their reading comprehension. A survey had been conducted to know more on the students' attitude towards reading strategies for comprehending reading materials. The subject of this study was 28 students of non-English department students in a college in Malang. The study found out that most of the students considered that using reading strategies in their reading process was not necessary even though they had shown a positive attitude towards the use of reading strategies. Moreover, the implementation of reading strategies had not been able to improve their motivation in reading a text in English because most of them were not fully motivated. Thus, it can be concluded that reading strategies should be taught explicitly to the students of non-English department for improving their reading comprehension and for developing a good reading habit.
\end{abstract}

Keywords: reading strategies, reading comprehension, reading attitude, non-English department students 


\section{INTRODUCTION}

Reading cannot be solely be seen as a way of improving or acquiring a language. With a rapid changing of a today's world, people are exposed with the rapid changes of information which is hardly able to be avoided. The information resources and the way to access the information also change inevitably. In order to keep updated with new information every time, reading is the way to acquire the information. Reading is a receptive skills in learning a language which is also important for the students to improve their academic performance, to shape the mind, to enrich vocabulary, to build character, to expand the perspective, among many other benefits (Erdem: 2015, Skenderi \& Ejupi: 2018). Kutay (2014) argued that the students' ability in thinking is improved through reading because reading provides the students with new construct and ideas. Through reading, the students developed their language and vocabulary which is important for their successful communication. Reading is considered as the best receptive skills in learning a language because through reading the students do not only learn a language, but they also have knowledge.

Lack of English knowledge, lack of vocabulary and incapability in using reading strategies might become the reasons of most higher education students, particularly the students of non-English department, to feel reluctance reading in L2. For becoming successful and strategic readers, reading strategies are crucial. Unfortunately, the nonEnglish department students are not taught about reading strategies which hinders their reading comprehension and fail in developing their reading habits, motivation and interest. For the students of non-English department, reading in L2 becomes a serious problem because they have to deal with many reading materials related to their study. When reading should be able to expand their horizon of knowledge, reading in L2 has become a less-liked activity which influences their academic performance later on.

It should be realized that reading is a complex cognitive process that includes many different factors. Erdem (2015) stated that reading has several stages of development. Understanding the use of reading strategies is a part of reading successfully and in order to have a good reading skills. Reading strategies enable them to approach and understand the reading materials with ease, either in their native language or in the second language. Reading strategies are the way for comprehending the texts and enable them to read the texts interactively. The students cannot automatically use these reading strategies for reading successfully. They need ample practices in order to change the reading strategies into reading skills. The students need to use the strategies consciously because cognitive process influences the use of reading strategies (Pudyastuti, 2017). According to the above mentioned issues on reading, it is crucial to find out the students' attitude towards reading strategies

\section{METHOD}

A survey based questionnaire was the method used in this study to know the students' perceptions on their reading skills. A questionnaire was distributed to the students to know their attitude towards reading strategies, particularly on scanning, skimming and making prediction. The questionnaire consisted of 27 questions on the students' understanding on reading strategies and their motivation in reading. The subject of this study was the students of non-English department of a private university in Malang. The questionnaire was filled out by 28 students of non-English department aged 19-20 years. This study was conducted to answer the following research question, "How is students' attitude towards reading strategies?" 


\section{RESULT}

The students' attitude towards reading is presented in detail in this section. The data was gathered from the questionnaire distributed to 28 students of Informatics Department in a private university. The students' responses were analyzed and interpreted. The results are presented in the form of tables.

According to Table 1, there were 21 students $(75 \%)$ who read English text within the previous week before they filled out the questionnaire. There were 3 students (11\%) who always read English texts and who never read English text within the previous week. And the number of student who read English many times within the week was 1 student (4\%). The result shows that most of the students read texts written in English even though it does not revealed the kinds of reading material they read.

Table 1: Did you read any English text within last week?

\begin{tabular}{l|c|c} 
Item 1 & Frequency & Percentage \\
\hline Never & 3 & $11 \%$ \\
Sometimes & 21 & $75 \%$ \\
Many times & 1 & $4 \%$ \\
Always & 3 & $11 \%$ \\
\hline
\end{tabular}

To response Item 2, which asked about the reading strategies used, as much as $57 \%$ students sometimes used reading strategies. As much as $18 \%$ of them never used reading strategies or used reading strategies many times when they read. There was only $7 \%$ of them who always used reading strategies. The reading strategies being asked in the questionnaire were scanning, skimming, and making prediction.

Table 2: If your answer is other than "Never", did you use scanning, skimming and making prediction?

\begin{tabular}{l|c|c} 
Item 2 & Frequency & Percentage \\
\hline Never & 5 & $18 \%$ \\
Sometimes & 16 & $57 \%$ \\
Many times & 5 & $18 \%$ \\
Always & 2 & $7 \%$ \\
\hline
\end{tabular}

The questions which asked about scanning were presented on Item 3 and Item 4. In responding Question 3 on making question before reading a text, most students (12 students or $43 \%$ ) never asked question before reading the text. There were 5 students $(18 \%)$ who sometimes asked question before reading text, 7 students $(25 \%)$ who asked questions before reading text and 4 students (14\%) who always asked questions before reading text.

Table 3: If you use scanning, did you make questions before reading the text?

\begin{tabular}{l|c|c} 
Item 3 & Frequency & Percentage \\
\hline Never & 12 & $43 \%$ \\
Sometimes & 5 & $18 \%$ \\
Many times & 7 & $25 \%$ \\
Always & 4 & $14 \%$ \\
\hline
\end{tabular}


The response of the students on Item 4 showed that they were able to identify the specific information in the text in different level. There were $25 \%$ of them ( 7 students) who were always able to identify the specific information in the text, $43 \%$ of them (12 students) who were able to identify it many times and 32\% (9 students) sometimes able to identify it. Even though their ability to identify the specific information is various, it can be assumed that the students can locate the specific information with less difficulties.

Table 4: Could you identify specific information in the text?

\begin{tabular}{l|c|c} 
Item 4 & Frequency & Percentage \\
\hline Never & 0 & $0 \%$ \\
Sometimes & 9 & $32 \%$ \\
Many times & 12 & $43 \%$ \\
Always & 7 & $25 \%$ \\
\hline
\end{tabular}

Thus, from the questions on scanning, a conclusion can be drawn that the students used scanning when reading English texts. They might have problems in using scanning, but some of them showed an ability to use this reading strategies. Although most of them did not have questions before reading, they can identify the specific information they need to find.

Item 5 to Item 8 asked the students about their ability in using skimming. In skimming, the students are required to get an overview of the content of the reading materials. Similar to scanning, the students read the English texts quickly in skimming to get the general information or idea in the text. From Table 5, it can be learned that $54 \%$ of the students (15 students) read the text quickly to get a content overview of the text. There were $25 \%$ of them ( 7 students) who read the text quickly many times. And, only $11 \%$ of them ( 3 students) who never and always read the text quickly to get the overview of the text content. Table 5 depicts the detail of the results of Item 5 .

Table 5: If you use skimming, did you read the text quickly to get an overview of its content?

\begin{tabular}{l|c|c} 
Item 5 & Frequency & Percentage \\
\hline Never & 3 & $11 \%$ \\
Sometimes & 15 & $54 \%$ \\
Many times & 7 & $25 \%$ \\
Always & 3 & $11 \%$ \\
\hline
\end{tabular}

Meanwhile, many students read the first sentence of the paragraphs to get the general idea of the text, or as much as 12 students (or 43\%). The number of students who always read the first sentence of the paragraphs were 6 students $(25 \%)$. There were 7 students (32\%) who read it sometimes. And only a small number of the students (or 3 students) who did not read the first sentence of the paragraphs. 
Table 6: Did you read the first sentence of the paragraphs to get the general idea of the text?

\begin{tabular}{l|c|c} 
Item 6 & Frequency & Percentage \\
\hline Never & 3 & $0 \%$ \\
Sometimes & 7 & $32 \%$ \\
Many times & 12 & $43 \%$ \\
Always & 6 & $25 \%$ \\
\hline
\end{tabular}

Another way to get the general idea of the text quickly is by reading the last sentences of the paragraphs. Item 7 asked the students on this particular term. The results of the students' response were similar to the results of Item 6, in which most of the students knew that they could get the general idea of the text quickly by reading the last sentence of the paragraphs. Table 7 depicts the detail results of Item 7. Most of the students $(46 \%)$ sometimes read the last sentence of the paragraphs to get the general idea of the text. There were $25 \%$ of them who read the last sentences many times and $18 \%$ of them who always read the last sentence of the paragraphs. And, there were only $11 \%$ of them who never read the last sentence of the paragraphs to get the general idea of the text.

Table 7: Did you read the last sentence of the paragraphs to get the general idea of the text?

\begin{tabular}{l|c|c} 
Item 7 & Frequency & Percentage \\
\hline Never & 3 & $11 \%$ \\
Sometimes & 13 & $46 \%$ \\
Many times & 7 & $25 \%$ \\
Always & 5 & $18 \%$ \\
\hline
\end{tabular}

Reading key words is also beneficial in skimming an English text. Out of 28 students, there were only 2 of them who never use key words to get the general idea of the text. And, there were 6 of them who always read the key words to get the general idea of the text quickly. Majority of the students, or 10 students, sometimes read the key words. The number of the students who read the key words many times were also the same. Table 8 shows the students response to Item 8 .

Table 8: Did you read the key words to get the general idea of the text?

\begin{tabular}{l|c|c} 
Item 8 & Frequency & Percentage \\
\hline Never & 2 & $7 \%$ \\
Sometimes & 10 & $36 \%$ \\
Many times & 10 & $36 \%$ \\
Always & 6 & $21 \%$ \\
\hline
\end{tabular}

From the results of four questions on skimming, it can be concluded that the students had already known how to skim the text better. They showed a good attitude in skimming the text.

Making prediction is another reading strategies that helps the students to read the text faster. There are several methods for making prediction of the text 
successfully. Item 9 to Item 13 asked the students about their attitude towards this strategy.

Item 9, which asked about the use of the title for making prediction, there were $36 \%$ of the students who many times read the title and $32 \%$ of them who always read the title for making prediction. And only $4 \%$ of them did not read the title for predicting the text.

Table 9: If you make prediction about the content of the text before reading, did you do it using the title of the text?

\begin{tabular}{l|c|c} 
Item 9 & Frequency & Percentage \\
\hline Never & 1 & $4 \%$ \\
Sometimes & 8 & $29 \%$ \\
Many times & 10 & $36 \%$ \\
Always & 9 & $32 \%$ \\
\hline
\end{tabular}

The students can use the features of the text, such as headings, italicized words, graphs, tables, pictures, etc., for making prediction of the text. The students' response to Item 10 which asked about the text features showed that most of the students used these features for making prediction. These features were used many times by 10 students (36\%) and were used always by 9 students (32\%). As much as $25 \%$ of the students did not use the features and the least number of students $(7 \%)$ used the features for making prediction of the text.

Table 10: Did you use the headings, italicized words, graphs, tables and pictures in the text to give you an idea about the content of the text before reading?

\begin{tabular}{l|c|c} 
Item 10 & Frequency & Percentage \\
\hline Never & 7 & $25 \%$ \\
Sometimes & 2 & $7 \%$ \\
Many times & 10 & $36 \%$ \\
Always & 9 & $32 \%$ \\
\hline
\end{tabular}

Item 11 asked the students' response about reading the first paragraph to know the context of the text. Table 11 depicts these results. It was found that most of the students read the first paragraph before reading the text. As much as $43 \%$ of them always read the first paragraph and $32 \%$ of them read the first paragraph sometimes. However, there were $11 \%$ of them did not read the first paragraph and $14 \%$ read the first paragraph many times. It assumes that reading the first paragraph of the texts is important to know the topic being discussed in the texts to be read further.

Table 11: Did you read the first paragraph to know about the content of the text?

\begin{tabular}{l|c|c} 
Item 11 & Frequency & Percentage \\
\hline Never & 3 & $11 \%$ \\
Sometimes & 9 & $32 \%$ \\
Many times & 4 & $14 \%$ \\
Always & 12 & $43 \%$ \\
\hline
\end{tabular}


Except reading the first paragraph, reading the last paragraph is also important to know the context of the text before reading. From the response, it can be learnt that the number of students who read the last paragraph were not as much as the number of students who read the first paragraph. It seems that reading the first paragraph is important to do to know the context of the text. Most of the students sometimes (36\%) or never $(32 \%)$ read the last paragraph for making prediction. The number of students who read the last paragraph many times was $6 \%$ and those who read it always was $3 \%$. Table 12 depicts the detail of the response on Item 12.

Table 12: Did you read the last paragraph to know the content of the text before reading?

\begin{tabular}{l|c|c} 
Item 12 & Frequency & Percentage \\
\hline Never & 9 & $32 \%$ \\
Sometimes & 10 & $36 \%$ \\
Many times & 6 & $21 \%$ \\
Always & 3 & $11 \%$ \\
\hline
\end{tabular}

Reading the summary is also a way to predict the content of the texts. Most of the students do this before reading the text. Table 13 shows that $50 \%$ of the students sometimes read the summary and $21 \%$ of them read the summary many times and always. The students who did not read the summary was as much as $7 \%$.

Table 13: Did you read the summary, if any, before reading the text?

\begin{tabular}{l|c|c} 
Item 13 & Frequency & Percentage \\
\hline Never & 2 & $7 \%$ \\
Sometimes & 14 & $50 \%$ \\
Many times & 6 & $21 \%$ \\
Always & 6 & $21 \%$ \\
\hline
\end{tabular}

Item 14 to Item 16 collected the data on the usefulness of each reading strategies. From these three items, it can be concluded that the students considered that reading strategies were useful for reading. They found that the three reading strategies were always useful for them as there were $11 \%$ responses for scanning and $14 \%$ responses for each skimming and making prediction. Those who stated that the strategies were useful many times were as much as $32 \%$ for scanning, $21 \%$ for skimming and $36 \%$ for making prediction. These strategies were found useful sometimes in which $39 \%$ gave response to the question on scanning and making prediction, and 54\% gave response to the question on skimming. $11 \%$ of the students did not think that reading the summary of texts were useful for both skimming and making prediction. And, $18 \%$ of the students did not find scanning useful for them in reading. Table 14 depicts the detail of the responses for each reading strategies. 
Table 14: The usefulness of scanning, skimming and making prediction

\begin{tabular}{l|c|c} 
Item 14 (Scanning) & Frequency & Percentage \\
\hline Never & 5 & $18 \%$ \\
Sometimes & 11 & $39 \%$ \\
Many times & 9 & $32 \%$ \\
Always & 3 & $11 \%$ \\
\hline Item 15 (Skimming) & Frequency & Percentage \\
\hline Never & 3 & $11 \%$ \\
Sometimes & 15 & $54 \%$ \\
Many times & 6 & $21 \%$ \\
Always & 4 & $14 \%$ \\
\hline Item 16 (Making Prediction) & Frequency & Percentage \\
\hline Never & 3 & $11 \%$ \\
Sometimes & 11 & $39 \%$ \\
Many times & 10 & $36 \%$ \\
Always & 4 & $14 \%$ \\
\hline
\end{tabular}

Table 15 asked the students response on the students' responsibility and commitment towards reading activities. Depicted from the table that, $43 \%$ of the students sometimes did the reading tasks or activities with responsibility and commitment, $29 \%$ of them did it with responsibility and commitment many times, and $25 \%$ of them always did it with responsibility and commitment. Meanwhile, there were only $4 \%$ of them who showed no responsibility and commitment in doing the reading tasks. From the result, it indicates that the students need to develop their responsibility and commitment in doing the reading tasks or activities. They might have the responsibility and commitment, but they still need encouragement in developing it.

Table 15: Do you do your activities or tasks with responsibility and commitment?

\begin{tabular}{l|c|c} 
Item 17 & Frequency & Percentage \\
\hline Never & 1 & $4 \%$ \\
Sometimes & 12 & $43 \%$ \\
Many times & 8 & $29 \%$ \\
Always & 7 & $25 \%$ \\
\hline
\end{tabular}

In terms of getting new vocabulary for improving the reading process, most of the students $(36 \%)$ looked up new vocabulary in their reading. Some of them $(32 \%)$ sometimes looked up the new vocabulary and $25 \%$ of them always looked up new vocabulary. Only $7 \%$ of them did not look up new vocabulary. According to the results shown, in general, students realized that knowing the meaning of new vocabulary is important to improve their reading process. It also important to understand the text. However, their dependency to find the meaning of new vocabulary were various. Table 16 depicts the result of Item 17 in detail. 
Table 16: Do you look up new vocabulary in texts to improve the reading process?

\begin{tabular}{l|c|c} 
Item 18 & Frequency & Percentage \\
\hline Never & 2 & $7 \%$ \\
Sometimes & 9 & $32 \%$ \\
Many times & 10 & $36 \%$ \\
Always & 7 & $25 \%$ \\
\hline
\end{tabular}

Item 19, as depicted on Table 17, asked the students' response whether they checked and read again the assigned readings to complement what they see in class. In response to this question, most of the students $(43 \%)$ of them did the activities many times. There were $32 \%$ of them who did it sometimes, $11 \%$ of them who did it always and $14 \%$ of them who never did it. The data indicates that having double check or reading the assigned reading materials in order to help them comprehending the reading materials.

Table 17: Do you check and read again the assigned readings to complement what you see in class?

\begin{tabular}{l|c|c} 
Item 19 & Frequency & Percentage \\
\hline Never & 4 & $14 \%$ \\
Sometimes & 9 & $32 \%$ \\
Many times & 12 & $43 \%$ \\
Always & 3 & $11 \%$ \\
\hline
\end{tabular}

Table 18 contains the response on the question about monitoring and selfassessment of the students' learning process. The question tried to find out the students' attitude dealing with difficulties that they might experience during the reading process. Form the table, it can be learnt that most of the students monitored and conducting self-assessment of their own learning process to overcome the difficulties. There were 10 students $(36 \%)$ did it sometimes and many times. However, there were still some students, $18 \%$ of them, who never monitored and self-assessed their learning process. This number was slightly different with the number of students who always (11\%) monitored and self-assessed their learning process to overcome the difficulties. It shows that the students understand the importance of monitoring and self-evaluation on their learning process so that they can understand the difficulties they experienced and the way to overcome the problems.

Table 18: Do you monitor and self-asses your own learning process to overcome any difficulties?

\begin{tabular}{l|c|c} 
Item 20 & Frequency & Percentage \\
\hline Never & 5 & $18 \%$ \\
Sometimes & 10 & $36 \%$ \\
Many times & 10 & $36 \%$ \\
Always & 3 & $11 \%$ \\
\hline
\end{tabular}


In responding Item 21, which asked the students about the usefulness of the reading strategies in other context, $43 \%$ of them said that it was useful in many occasions and $36 \%$ said that it was useful in some occasions. However, there were $11 \%$ of the students said that it was always useful and $11 \%$ said that it was not useful to use reading strategies in other context. It can be learnt that the students considered that reading strategies were needed in many other context and situation of their learning process. The detail results of this item is depicted in Table 19.

Table 19: Do you think that the strategies implemented in class are useful for you to use in other contexts?

\begin{tabular}{l|c|c} 
Item 21 & Frequency & Percentage \\
\hline Never & 3 & $11 \%$ \\
Sometimes & 10 & $36 \%$ \\
Many times & 12 & $43 \%$ \\
Always & 3 & $11 \%$ \\
\hline
\end{tabular}

Reading engagement can be achieved by implementing reading strategies in the reading process. According to Table 20, only a small number of students $(7 \%)$ considered that the use of reading strategies did not engage them to read more in English. There were $39 \%$ of them engage to read more sometimes by using reading strategies. $36 \%$ of them thought that using reading strategies many times engaged them to red more in English. And, $18 \%$ of them considered that it was necessary to use reading strategies to have a good reading engagement in reading English text.

Table 20: Do you think that the strategies implemented in class are useful for you to use in other contexts?

\begin{tabular}{l|c|c} 
Item 22 & Frequency & Percentage \\
\hline Never & 2 & $7 \%$ \\
Sometimes & 11 & $39 \%$ \\
Many times & 10 & $36 \%$ \\
Always & 5 & $18 \%$ \\
\hline
\end{tabular}

Also, to some different degrees, the students believed that using reading strategies helps their reading process better. The biggest number of the students, or $43 \%$ of them, believed that their reading process was better at many times when they used reading strategies. Some of them (36\%) always believed that the use of reading strategies improved their reading process to be better. Even though there were $21 \%$ of them believed that the use of reading strategies sometimes beneficial to improve their reading process to a betterment, none of them against it. The results prove that the students can read better when they implement the reading strategies. Table 21 depicts the students' response on Item 23 in detail. 
Table 21: Do you believe that the reading process is better when you use reading strategies?

\begin{tabular}{l|c|c} 
Item 23 & Frequency & Percentage \\
\hline Never & 0 & $0 \%$ \\
Sometimes & 6 & $21 \%$ \\
Many times & 12 & $43 \%$ \\
Always & 10 & $36 \%$ \\
\hline
\end{tabular}

The three reading strategies being discussed in this study helps the students to select their reading materials with ease. Item 24 was asked to know the students' perception on the use of reading strategies to be selective in reading. None of the students who considered that reading strategies did not useful for selecting their reading. However, $29 \%$ of the students always used reading strategies for selecting their readings. Most of the students, or 39\% of the students, sometimes used reading strategies for being selective in reading and $32 \%$ of them used the strategies for the particular purpose many times. It indicates that reading strategies are important in selecting English text. The details of the responses are presented in Table 22.

Table 22: Do the reading strategies help you to be selective in reading?

\begin{tabular}{l|c|c} 
Item 24 & Frequency & Percentage \\
\hline Never & 0 & $0 \%$ \\
Sometimes & 11 & $39 \%$ \\
Many times & 9 & $32 \%$ \\
Always & 8 & $29 \%$ \\
\hline
\end{tabular}

In relation to autonomy, Item 25 asked the students' perception on their autonomy when they were given a chance to choose their own topic of reading. Most of the students $(46 \%)$ thought that sometimes having the option of selecting the topics of their reading based on their interest improved their autonomy to read about other subjects. There were $29 \%$ of them thought that having an opportunity to select their topics of reading according to their interest improved their autonomy at many times and $21 \%$ stated that it would always improve their autonomy. $4 \%$ of the students stated that the opportunity did not improve their autonomy to read more about other subjects. The results indicates that the students had already had an autonomy to read more but it needs to be improved more so that they can have a good reading habit. Table 23 presents the results of Item 25 in detail.

Table 23: Do you think that having the option of selecting topics of your interest has promoted more autonomy to read about other subjects?

\begin{tabular}{l|c|c} 
Item 25 & Frequency & Percentage \\
\hline Never & 1 & $4 \%$ \\
Sometimes & 13 & $46 \%$ \\
Many times & 8 & $29 \%$ \\
Always & 6 & $21 \%$ \\
\hline
\end{tabular}


Most of the students stated that their reading skills were improved after they implemented reading strategies in their reading process. As much as $39 \%$ of the students gave response to "sometimes" and $36 \%$ of them gave response to "many times" for Item 26 which asked whether their reading skills had improved after the implementation of reading strategies. However, there were $14 \%$ of them said that the implementation of reading strategies did not improve their reading skills. And, there were only $7 \%$ of them who stated that reading strategies implementation really improved their reading skills. The data of students' response on Item 26 is presented in Table 24.

Table 24: Have you improved your reading skills after the implementation of reading strategies?

\begin{tabular}{l|c|c} 
Item 26 & Frequency & Percentage \\
\hline Never & 4 & $14 \%$ \\
Sometimes & 11 & $39 \%$ \\
Many times & 10 & $36 \%$ \\
Always & 2 & $7 \%$ \\
\hline
\end{tabular}

The last question on the questionnaire asked the students' response in terms of their motivation in reading text in English when they were able to use reading strategies. The responses for this questions is presented in Table 25. From the table, it shows that there were a small number of the students $(21 \%)$ who felt motivated in reading a text in English after they were able to use reading strategies. For most of the students, their motivation still need to be improved more. And, there were $7 \%$ of the students who were lack of motivation in reading an English text even though they were able to use reading strategies.

Table 25: Do you feel motivated in reading a text in English when you are able to use the reading strategies?

\begin{tabular}{l|c|c} 
Item 27 & Frequency & Percentage \\
\hline Never & 2 & $7 \%$ \\
Sometimes & 12 & $43 \%$ \\
Many times & 7 & $25 \%$ \\
Always & 6 & $21 \%$ \\
\hline
\end{tabular}

Only a small number of students that use reading strategies efficiently and effectively and consider that employing reading strategies are useful for them in comprehending the texts. Meanwhile, most of the students use the reading strategies inefficiently and ineffectively and find out that the reading strategies are not useful for them in reading comprehension. Specifically, the students do not ask questions before reading the text although they are able to identify specific information in the text. In order to get an overview or the general idea of the text, most of the students do not use the skimming strategy efficiently and effectively either. They read the first sentence of the paragraphs only without reading the last sentence of the paragraphs. They are also able to use the key words for getting the general idea of the text. The students are considered as good in predicting the content of the text before reading by employing the title, the headings, italicized words, tables, graphs, pictures available in the text, 
and by reading the first paragraph of the text. Unfortunately, there are many of them do not use the summary or do not read the last paragraph for predicting the content of the text.

\section{DISCUSSION}

According to the results, it can be learnt that the students of non-English department have positive attitude towards reading strategies as only small number of them gave response to "Never" in all answers. However, the students who chose to answer "Always" also were not many. Thus, it can be concluded that the students have shown their positive attitude or good perceptions towards reading strategies, yet there are things to be improved or developed in the students to have more positive attitude in the future. Reading attitude is a feeling about reading in an individual which cause the students to adopt or avoid reading. The students' attitude towards reading is closely related to their willingness to read texts in English and the way they approach reading situation (Owusu-Acheaw \& Larson, 2014). However, the students of non-English department need to be encouraged more in using reading strategies in their reading process in order to improve or to develop their reading habit and motivation to read. The results of this study also indicate that the students knew about reading strategies and understood the importance of using reading strategies. Yet, it has not been able to improve their motivation in reading.

In terms of motivation, it is found that the students of non-English department still have lack of motivation in reading. Even though they had learnt on using reading strategies, most of the students were unmotivated to read more text in English. In order to get the benefits of reading, having a good reading habit is necessary. When the students have lack of motivation, it might be difficult to have a good reading habit. Reading habit of the students is interrelated to their academic performance because to have a good academic performance requires the students to explore or to investigate personally. Moreover, having a good reading habit, which should be initiated from the early age of life, is important for developing an educated student and a literate community. Reading habits are measured according to how much a person read, how often they read, when they read and what they read. (Owusu-Acheaw \& Larson, 2014; Rosli et al, 2017). Reading habits can be developed by many different factors, such as age, gender, job and lifestyle. This habit can become the need of an individual when the person continues to develop it. They need to read reading materials, not only for searching for information and having a good academic performance, but also for relaxing, for the tranquility of the mind from routines and for better self-expression. Erdem (2015) mentioned that developing reading habit of the students is a fundamental objective of learning.

The teaching of reading strategies for the non-English department students can be considered to be improved. These students learn English in the English for Specific Purposes (ESP) class in which the students should deal with many content-area reading texts. The students are required to comprehend English texts related to their field of study, yet they are not trained to use reading strategies in order to help them to comprehend the texts successfully. The teaching of reading strategies is not taught in the ESP class explicitly, even though these strategies are beneficial in comprehending the content-area reading texts. This condition hinders the students' success in comprehending the texts. Moreover, reading strategies enable them to be a strategic reader because they can use these strategies efficiently, effectively and fluently in their 
reading process (Pudyastuti, 2017). She also mentioned that the impact of not teaching reading strategies explicitly in this class, the students have less interest in reading English texts, either for specific purposes or for general purposes. Another impact is that reading texts in English is difficult for the non-English department students. If these persistent problems are ignored, the students might have problems in building or acquiring new knowledge, ideas, and innovations. Thus, teaching reading explicitly to the students is considered to be crucial and important for the students of non-English department. The students can practice more in using the reading strategies when the reading strategies are taught in the ESP class.

Ability in using reading strategies helps the students to be a strategic reader because they are able to use the strategies efficiently and effectively. An efficient reader can determine and identify which reading strategies should be used for different purposes of reading and different reading materials. An efficient reader is able to combine the reading strategies in their reading activity. When reading strategies are used efficiently and effectively, an active reader is developed because an active reader uses different reading strategies unconsciously to meet their goals of reading (Grabe, 2009; Pudyastuti, 2017). Moreover, Renandya (2015) argued that the difference between a good reader and a poor reader is in their ability in using the strategies efficiently and effectively.

\section{CONCLUSION}

This study has shown that the students of non-English department should be able to comprehend in using reading strategies. Reading strategies are important for improving their reading habit, attitude, motivation and interest. Reading strategies enable them to be a strategic reader which help them to read efficiently and effectively. Comprehending the reading strategies is important for improving the academic performance of the non-English department students. Thus, the teaching of reading strategies should be accommodated in the ESP class.

However, another study on the implementation of teaching reading strategies to the non-English department students is necessary to be conducted. Since this study was limited to three reading strategies, it is also necessary to conduct a further study on other reading strategies.

\section{REFERENCES}

Erdem, A. 2015. A Research on Reading Habits of University Students: (A Sample of Ankara University and Erciyes Unviersity). Procedia - Social and Behavioral Sciences, 174, 3983-3990

Grabe, W. 2009. Reading in a Second Language: Moving from Theory to Practice. New York: Cambridge University Press.

Kutay, V. 2014. A survey of the reading habits of Turkish high school students and an examination of the efforts to encourage them to read (unpublished master's thesis).

Loughborough University. Retrieved from https://dspace.lboro.ac.uk/dspacejspui/bitstream/2134/15786/3/Thesis-2014-Kutay.pdf 
Owusu-Acheaw, M., \& Larson, A. G. 2014. Reading Habits among Students and Its Effect on Academic Performance: A Study of Students of Koforidua Polytechnic. Library Philosophy and Practice (e-journal). 1130. Retrieved from http://digitalcommons.unl.edu/libphilprac/1130

Pudyastuti, Z.E. 2017. Improving Non-English Department Students' Ability in Comprehending Texts by Introducing Reading Strategies. Universitas Negeri Malang: Unpublished Master's Thesis.

Renandya, W.A. 2015. Reading In A Foreign Language: What Else Is Important Besides Skills And Strategies? In Hamied, F.A., Yadnya, I.B.P., Soclowati, I.G.A.G. (Eds.). Developing Indegenous Models of English Language Teaching Assessment. Denpasar: Udayana University Press. Retrieved from http://www.academia.edu/19568631/Reading_in_a_foreign_language_What_el se_is_important_besides_skills_and_strategies

Rosli, N.A., Razali, N.F., Zamil, Z.U.A, Noor, S.N.F.M, Baharuddin, M.F. 2017. The Determination of Reading Habits among Students: A Concept. International Journal of Academic Research in Business and Social Sciences, 7(12), 791-798. DOI: $10.6007 / \mathrm{IJARBSS} / \mathrm{v} 7-\mathrm{i} 12 / 3710$

Skenderi, L., Ejupi, S. 2017. The Reading Habits of University Students in Macedonia. Conference Paper of $15^{\text {th }}$ International Conference "Knowledge in Practice". Retrieved from https://www.researchgate.net/publication/328492200_THE_READING_HABI TS_OF_UNIVERSITY_STUDENTS_IN_MACEDONIA 